Volume 13 Number 1, January-March 2019: pp. 87-100. Copyright (c) 2019 FIAT JUSTISIA. Faculty of Law, Lampung University, Bandarlampung, Lampung, Indonesia. ISSN: 1978-5186 | e-ISSN: 2477-6238.

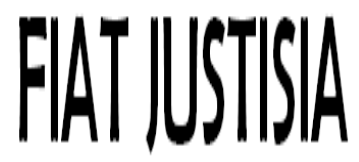

Fiat Justisia is licensed under a Creative Commons Attribution 4.0 International License, which permits unrestricted use, distribution, and reproduction in any medium, provided the original work is

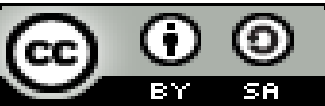
properly cited.

\title{
Optimisation of the Application of Legal Aid for the Poor People in Sukabumi City
}

\author{
Haidan Angga Kusumah \\ Faculty of Law, University of Muhammadiyah Sukabumi, Indonesia \\ haidananggakusumah16@gmail.com \\ Agus Rasyid Chandra Wijaya \\ Faculty of Law, University of Muhammadiyah Sukabumi, Indonesia \\ dsn.agus.rasyid.cw@gmail.com
}

\begin{abstract}
The background of this research is that access to the implementation of legal aid for the poor that is held by the state is still not effective, especially the poor in the area of Sukabumi City in terms of legal assistance by Legal Aid Providers is still not well coordinated. So research was carried out to describe descriptively about the optimisation of the application of legal aid for poor people in the area of Sukabumi City. The research method used is analytical descriptive, which describes the data from the relevant material existing and analyses it by referring to the Juridical basics. The results Showed that the optimisation of the application of legal aid for the poor people in the Sukabumi City area could be Tirrenus by government awareness in evaluating the condition of $\mathrm{LBH}$ in the region.
\end{abstract}

Keywords: Legal Assistance, Poor People

How to Cite: Haidan Angga Kusumah dan Agus Rasyid Chandra Wijaya, "Optimization of the Application of Legal Aid for the Poor People in Sukabumi City ", Fiat Justisia, 13 (1), (2019).

DOI: https://doi.org/10.25041/fiatjustisia.v13no1.1564 


\section{A. Introduction}

Legal aid is the right of poor people who can be obtained free of charge (pro bono publico) as the elaboration of equality before the law. Based on the rules of origin 34 of the Constitution (Constitution) in 1945 confirms that the poor are the responsibility of the state. Specifically referring to the principle of equality before the law (equality before the law) and the right to be defended Advocate (access to legal counsel) is a human right (HAM) that need to be secured in the framework of poverty alleviation Indonesia. Article 34 paragraph (1) of the 1945 Constitution states that the poor and abandoned children reared by the state. The article also shows that the state is responsible for guaranteeing the economic, social, political, and cultural as well as including the right to legal aid. Coupled with Article $28 \mathrm{D}$ which states that every person has the right to the recognition. In 2011 the Government issued Law No. 16 the on 2011 of Legal Aid which aims to maximise the provision of legal aid for the poor. The law their expected legal aid for the poor can be accessed easily. But in reality many people are pessimistic about the effectiveness of these laws, ${ }^{1}$ This is supported by research Pujiarto, Kalo, the Son, and Ikhsan that ${ }^{2}$ "Granting legal aid to the poor regulated in Law Number 16 Year 2011 on Legal Aid does not run according to the rules, terms as Executive Legal Aid hinder the provision of legal, judicial assistance does not run as expected".

The state does not organise application of legal aid for poor people is not maximised and not evenly distributed to the regions. This is because many poor people who do not know or even understand their access to legal aid. Channelling right to legal aid to the poor implementation is uneven in Indonesia, especially in West Java province. Like the poor city of Sukabumi in mentoring-legal assistance is still not coordinated and realised well. For example, in the provision of legal aid services free of charge, is still due to technical obstacles and constraints in the field access to legal counsel. The backward technique constraints in the application of legal aid in the city of Sukabumi, (1) there are many omission of law enforcement officials, especially police officers, prosecutors, judges from the beginning of the investigation until the trial. The poor do not appoint an advocate so may be accompanied, so many of them walk alone without particularly ordinary people and do not understand the law. (2) OBH/LBH in the city of Sukabumi has not been accredited or are still in the administrative process for

\footnotetext{
1 A Krustiyati, "Optimalisasi Perlindungan dan Bantuan Hukum Pekerja Migran melalui Promosi Konvensi Pekerja Migran tahun 2000”, Dinamika Hukum, Vol. 13 No. 1, (2012), pp. 136-147.

${ }^{2}$ Suyogi Imam Fauzi, Inge Puspita Ningtyas, "Pelaksanaan Pemberi Bantuan Hukum Dikaitkan dengan Bantuan Hukum Dikaitkan dengan Undang-undang No. 16 tahun 2011 tentang Bantuan Hukum", Jurnal Arena Hukum, Vol. 8 No.16, (2011), pp. 318-341.
} 
accreditation at the Ministry of Justice and Human Rights. Therefore, the provision of assistance to the poor in Sukabumi is still very difficult and has not been effective.

The gap at the top indicates misalignment between reality with the mandate of Law No. 16 of 2011 on Legal Aid. From these things, a lot of poor people who need legal aid is not met their rights in obtaining legal aid, and it is contrary to what is stated in the constitution in 1945 and the statute of legal aid. Theoretically, legal aid is the constitutional right of every citizen on legal protection and guarantees equality before the law, as a means of recognition of human rights. Getting legal help for everyone is the embodiment of access to justice (access to justice) as the implementation of legal protection and guarantees equality before the law. ${ }^{3}$ The term legal aid itself is used as a translation of two different terms, namely "Legal Aid" and "Legal Assistance". Legal Aid term usually used to show understanding of legal aid in the narrow sense of the provision of services in the field of legal services to a person involved in a case for free/free, especially for those who are less fortunate. While understanding the Legal Assistance is used to show understanding of legal aid by advocates who use honorarium. ${ }^{4}$

Based on Law No. 16 on 2011 of Legal Aid from now on referred to as the Legal Aid Act), Article 1 paragraph 1 stated that legal aid is a legal service provided by the Legal Aid for free to the recipient of legal aid. Legal Aid Recipients are persons or groups of poor people who cannot meet their basic right to a decent and independent who face legal problems. While the general provisions in point 2 , it is mentioned that the Legal Aid Recipients are persons or groups of poor people.

Furthermore, in Article 3 of the Law on Legal Assistance stated that the implementation of legal aid aims to: ensure and fulfil the right to Legal Aid Recipient to obtain access to justice; realizing the constitutional rights of all citizens in accordance with the principle of equality before the law, guaranteeing the implementation of the Legal Aid implemented evenly across the territory of the Republic of Indonesia; and realize the justice that is effective, efficient and accountable. Handayani (2015, p. 15) that ${ }^{5}$ legal assistance is "an attempt to fill the human rights, especially for the poorest sections of society. The Constitution guarantees the right of every citizen to

\footnotetext{
3 Pujiono, (2010). Bantuan Hukum dalam Perspektif Tanggungjawab Negara. Retrieved September 15, 2018, from http://www.mitrahukum.org/publikasi/opini/bantuan-hukum-dalamperspektif tanggungjawab-negara.

${ }^{4}$ Pujiono. (2010). Bantuan Hukum dalam Perspektif Tanggungjawab Negara. Retrieved September 15, 2018, from http://www.mitrahukum.org/publikasi/opini/bantuan-hukum-dalamperspektif tanggungjawab-negara.

${ }^{5}$ Tri Astuti Handayani, "Bantuan Hukum bagi Masyarakat Tidak Mampu dalam Perspektif Teori Keadilan Bermartabat”, Jurnal Refleksi Hukum, Vol.9 No.1, (2015), pp.15-24.
} 
equal treatment before the law, including the right to access justice through legal aid ".

The poor face major obstacles not only in financial terms related to the costs of the case but also synonymous with low education levels, which implies the lack of their knowledge of the legal issues when it should bring its case to court. Legal aid is the right of poor people who can be obtained free of charge (pro bono publico) as the elaboration of equality before the law ${ }^{6}$. This is by the provisions of Article 34 UUD 1945 confirms that the poor are the responsibility of the state. Article 34 paragraph (1) of the 1945 Constitution states that the poor and abandoned children reared by the state. The article extensively this also means the state is responsible for guaranteeing the economic, social, political, and cultural as well as legal for the poor, including the right to legal aid. ${ }^{7}$

The Constitution guarantees the right of every citizen to equal treatment before the law, including the right to access justice through legal aid.

Nonetheless judicial highly bureaucratic, expensive, complicated (procedural), it is esoteric (can only be understood among the law), cause not everybody gets access and equal treatment when dealing with the law, especially for poor people. The rich man and have the power, with easy access and obtain "justice", through the hands of a lawyer (Advocate) rented.

On the one hand, the poor cannot understand the law and the difficulties to pay the Advocate, it thus causing no equal treatment before the law to access justice. Article 56 of Law 48 of 2009 on Judicial Power states that any person implicated in the case are entitled to legal aid and the state bear the costs of the case for justice seekers who cannot afford. ${ }^{8}$

Also, law enforcement officers have a very important role in law enforcement, for law enforcement officers have the authority to enforce the law by their respective authorities. In the hands of law enforcement officers are abstract legal provisions that will be something concrete in public life. Is that a good law can be enforced properly, and laws that are less well able to be better in practice or otherwise, all depend on the law enforcement officers themselves 9 , This is because "every legal aid has a significant role in the access to justice so that not only can grow new hope in a world of justice but also a proof of the same justice for anyone under the law". ${ }^{10}$ Neither the police, judiciary, and the District Court as law enforcement officers have a very important role in the process of law enforcement for the sake of upholding

\footnotetext{
${ }^{6}$ Law Number 16 on 2011 of Legal Aid.

${ }^{7}$ Law Number 16 on 2011 of Legal Aid.

${ }^{8}$ Law Number 48 on 2009 of Judicial Power.

${ }^{9}$ Law Number 48 on 2009 of Judicial Power.

${ }^{10}$ Mustika Kusumawati, "Peranan dan Kedudukan Lembaga Bantuan Hukum sebagai Access to Justice bagi Orang Miskin”, Jurnal Arena Hukum, Vol. 9 No.2, (2016), pp. 190-206.
} 
justice for the people who have broken the law. Aside from the three law enforcement agencies tasked to represent the country, while the other is law enforcement advocate, who is a law enforcement a free and independent duty to represent the interests of the people as mandated in Law No. 18 on 2013 of the Advocate, whose job is to help people in the fulfilment of their rights to legal assistance.

Then in general, Miranda Principle asserts the basic human rights or constitutional rights of suspects which essentially includes: ${ }^{11}$

a. The right to not answer or silence before being checked and before the investigation (a right to Werner in silent);

b. The right to bring legal counsel and the right to consult before the examination or investigation by the investigator (a right to the presence of an attorney or the right to Council);

c. The right to be provided counsel for the suspect or defendant who cannot afford.

In practice in the application of legal aid to the poor people who have assisted their rights in compliance with legal aid still has obstacles and barriers, among them is still a problem is related to access to legal aid for the people of the region, especially uneven / still weak, the role of enforcer law to provide services to access legal aid is not optimal, budget-related legal assistance provided by the state to aid / LBH has not been absorbed into the area, and the obstacles more relevant understanding of the poor themselves who require legal assistance to access legal aid organized by the government has not been good. When referring to Musjtari (2015), Efforts should be made to enhance the legal awareness of society is the community service Real Work Lecture Learning for Community Empowerment (KKN PPM). Such activity includes mapping and population census, to import data from interviews and visits, as well as the mapping according to the characteristics of each population. This mapping can be used as a basis for policy-making apparatus hamlet in developing programs and activities. One benefit is to determine the potential of public awareness, as well as mapping solution. ${ }^{12}$

Based on previous translation, then drafted formulation of research problems namely "how to optimise the application of legal aid for the poor in the city of Sukabumi". In order to answer research questions, the researchers will conduct a review of four aspects: (1) Role and Function of Law Enforcement Authorities Regarding Legal Aid; (2) Application of Legal Aid Effectiveness Already Implemented; (3) Providing Assistance average in

\footnotetext{
${ }^{11}$ Himawan, S, "Bantuan Hukum bagi Terdakwa Tindak Pidana di Bidang Pertambangan pada Tahap Penuntutan", Jurnal Arena Hukum, 6(3), (2013), pp. 86-101.

${ }^{12}$ Musjtari, D. N, "Pembangunan Kesadaran Hukum Masyarakat Dusun Jetis, Desa Jetis, Kecamatan Saptosari, Kecamatan Gunung Kidul”, Jurnal Abdimas, Vol. 22 No.22, (2015), pp.151-160.
} 
Each Institution Law Enforcement Per-years; and (4) Recommendations to the Government in the administration of legal aid.

\section{A. Method}

This research includes descriptive, analytical research, which describes the existing data from the relevant material and analyzes it with reference to the fundamentals of the juridical, ${ }^{13}$ This research method is empirical juridical approach ${ }^{14}$ This approach is intended to carry out a review of legislation which is closely related to the central theme of research, ${ }^{15}$ The data collection process includes: (1) literature study to obtain or seek conceptions, opinions or findings relating to the subject matter of legislation, national policy development of lagging regions, legal expert opinion or the like. (2) The field study through interviews with some informants includes Mira (Police Resort Kota Sukabumi Sub-bag law), Febrian (State Attorney Sukabumi), Ivan Faizal (Posbakum District Court of the city of Sukabumi) and Yosep (Chairman LBH DPC Congress of Indonesian Advocates Sukabumi). The process of data collection is done in the area of the rule of law Sukabumi. The data will be analysed qualitatively to interpret, describe, and analyze to answer the problem formulation previously defined.

\section{B. Discussion}

The data collection in the field is done by in-depth interviews for two months done gradually by the agencies both police, prosecutors, the District Court of Sukabumi, and OBH / LBH. It aims to compare various viewpoints resource on "Optimizing Application of Legal Aid Work for the Needy In Sukabumi City Region" appropriate formulation of research problems:

\section{The Role and Function of Law Enforcement Authorities Regarding Legal Aid}

According to the view of Ms Mira ${ }^{16}$, If the penalty is less than five years it had no obligation under the law is to be accompanied or not accompanied by legal counsel, but we, as the police do not prohibit to the legal problems like whether accompanied by Counsel legal or not it, please. Mr Febrian ${ }^{17}$ said that during this time the District Attorney of Sukabumi has roles and

\footnotetext{
${ }^{13}$ Hanitijo R, Metode Penelitian Hukum dan Jurimetri. Bogor: Ghalia Indonesia, (1983), p. 10 ${ }^{14}$ Marzuki, P. M, Penelitian Hukum, Surabaya: Kencana, (2005), p. 35.

${ }^{15}$ Ibrahim J, Teori dan Metodologi Penelitian Hukum Normatif. Malang: Bayumedia Publishing, (2008), p. 285.

${ }^{16}$ Mira. (2018). Interviews related to the Optimization of the Application of Legal Aid for the Poor in the Sukabumi City Region. Sukabumi City.

${ }^{17}$ Febrian. (2018). Interviews related to the Optimization of the Application of Legal Aid for the Poor in the Sukabumi City Region. Sukabumi City.
} 
functions to serve the poor people who have problems with criminal law. If there is a punishable criminal suspect over the five-year statutory mandatory must be accompanied by the Legal Adviser. Therefore we as law enforcement agencies shall have to provide the public with the organisation in collaboration with the lawyers in the appointment of legal counsel. $\mathrm{Mr}$ Faizal ${ }^{18}$ said that the State Court Posbakum Sukabumi as a container for the aspirations, concerns, or anything related to either the criminal law or the civil law. If there are people who are not able to require legal assistance, Posbakum District Court of the city of Sukabumi airport if anyone wants consultation and or want to be assisted.

Mr Yosep ${ }^{19}$ said that lawyers in the profession had undergone the rights and obligations stipulated in the Advocates Act No. 18 of 2003 by Article 14 to Article 20. Likewise clearly in Article 22 is clear that the advocates are obliged to help the poor/helpless who need legal aid to seek justice. Based on the explanation of each informant, it can be seen that the role and functions of law enforcement authority on legal aid include:

a. Applying any obligation outlined in legislation on Article No. 182003 Articles 14 to 20.

b. Determine the categories of assistance to people who are involved in violations of the law by criminal or civil performed.

c. Provide legal aid assistance in the form of consulting services related to the complaint, aspiration or misconduct by the poor.

Tasks and roles have been regulated in Law No. 16 In $2011^{20}$ on Legal Aid to the poor. Because of it's regulated by the government, the law enforcement agencies must carry out these three as well as other points listed in the legislation. Also, the advocate in charge can apply the concept of Miranda Principle ${ }^{21}$ to meet the basic human rights or constitutional rights of suspects of the poor in Sukabumi.

\section{Application of Legal Aid Effectiveness That Already Implemented}

According to the view Ms Mira ${ }^{22}$, The application of legal aid conducted by the Police of Sukabumi, especially in the financial crimes unit in providing legal aid services is good enough for people who cannot afford. Most suggesting all relevant elements of both the government and law enforcement

\footnotetext{
${ }^{18}$ Faizal, I. (2018). Interviews related to the Optimization of the Application of Legal Aid for the Poor in the Sukabumi City Region. Sukabumi City.

${ }^{19}$ Yosep. (2018). Interviews related to the Optimization of the Application of Legal Aid for the Poor in the Sukabumi City Region. Sukabumi City.

${ }^{20}$ Law Number 16 on 2011 of Legal Aid.

${ }^{21}$ Himawan Setianto, "Bantuan Hukum bagi Terdakwa Tindak Pidana di Bidang Pertambangan pada Tahap Penuntutan”, Jurnal Arena Hukum, Vol. 6 No.3, (2013), pp. 86-101.

${ }^{22}$ Mira. (2018). Interviews related to the Optimization of the Application of Legal Aid for the Poor in the Sukabumi City Region. Sukabumi City.
} 
agencies should regularly provide for dissemination to the public so litigious, and they also need to know the name of access legal aid. Mr Febrian ${ }^{23}$ argued that providing legal aid services are good enough for people who cannot afford the legal problems. The obstacles most we've been hard to find an advocate for the appointment of legal counsel minimum sentence of five years, perhaps because in the area, so the number of personnel is still limited advocate for help related legal assistance. Mr Faizal ${ }^{24}$ said the adoption of legal aid had been well done; it might be to increase socialisation needs to be regularly to the public on the importance of their litigious legal aid.

Then Mr. Yosep ${ }^{25}$ said that the role of lawyers in carrying out its duty to help the people who need legal help free of charge, especially for people who cannot afford / poor run by LBH(s) in the city of Sukabumi is still not effective, due to the quantity number of $\mathrm{LBH}$ is still limited and the personnel advocates who handle his case still limited. Moreover, in terms of quality advocates in the city of Sukabumi still lacking in handling it professionally. Based on the explanation from the standpoint of the informant as a law enforcement agency in the city of Sukabumi classified has been quite effective. Categories are enough to show that the organisation of legal assistance to the poor already running properly. It is evidenced by the assistance that has been done to the poor affected by the punishment over five years. Mentoring five-year sentence is mandatory, as stipulated by law as a form of special protection for the poor in Indonesia. Protection aims to provide the widest access to information to all levels of society in Indonesia.

Also, the effectiveness of the application of legal aid in the area of Sukabumi still need recommendations relating to strategic planning and implementation. The planning includes the preparation of human resources (HR) has the willingness and credibility to advocate various criminal acts, especially the poor were punished over a five-year sentence. Besides, the need for targeted public awareness through the dissemination or special training to create a common understanding of the donor as well as the recipient of legal aid. It is important to note to realise the implementation of legal aid effectively and efficiently. On implementation, the LBH /OBH is limited in quantity in embracing all the complaints of the poor. It is very influential on the provision of legal aid in the city of Sukabumi, because each case has a different type of offence, so that an advocate must be adjusted to the type of the case. Therefore, the number of LBH / OBH still needs to be

\footnotetext{
${ }^{23}$ Febrian. (2018). Interviews related to the Optimization of the Application of Legal Aid for the Poor in the Sukabumi City Region. Sukabumi City.

${ }^{24}$ Faizal, I. (2018). Interviews related to the Optimization of the Application of Legal Aid for the Poor in the Sukabumi City Region. Sukabumi City.

${ }^{25}$ Yosep. (2018). Interviews related to the Optimization of the Application of Legal Aid for the Poor in the Sukabumi City Region. Sukabumi City.
} 
improved in quantity to accommodate more poor people who need legal assistance. The creation of harmony between the number of cases with LBH / OBH will create efficiencies in planning and its implementation.

Conditions certainly contrary to the statement Handayani (2015) that ${ }^{26}$ legal aid is a human right, especially for the poorest sections of society. The Constitution guarantees the right of every citizen to equal treatment before the law. This condition affects the quality of the role and functions of law enforcement in the city of Sukabumi. Therefore, law enforcement agencies require special strategies for improving the quality of legal assistance to the poor in Sukabumi. It is to achieve effective implementation of legal aid, the whole society to know, understand, and legal aid is good and progressive.

\section{Providing Assistance average in Each Institution Law Enforcement Per-years}

According to the view, Ms Mira ${ }^{27}$ said that the legal aid cases per year are more or less under the 400 cases for the year, but not all cases we offer legal counsel to be assisted. At most about $20 \%$ the minimum sentence of five years that we offer because it was obliged to be accompanied by legal counsel. But not all cases are entirely into the prosecutor and the court because the evidence is incomplete and still under investigation and there is also a dismissal of the case or SP3 because of insufficient evidence of a crime. $\mathrm{Mr}$ Febriani ${ }^{28}$ said on the matter was approximately 250-300 annually criminal cases, but not all cases these are legal assistance. At least for legal aid approximately $20 \%$ of it to the case of legal aid that the minimum sentence of five years, the remaining $80 \%$ there is a case that is not accompanied by legal counsel as threatened under five years and there is also a case the offender criminal using your legal counsel.

Mr Faizal ${ }^{29}$ said that for legal aid cases per year was below the 300 cases for the last year, but it was not all cases accompanied. Most around $20 \%$ the minimum sentence of five years, accompanied surely unless the person refuses. While the cases punishable under five years, there are only consultations, there were accompanied and unaccompanied mostly when in court. While Mr Yosep ${ }^{30}$ said that the number of cases in the city of Sukabumi

\footnotetext{
${ }^{26}$ Tri Astuti Handayani, Op.Cit, pp.15-24.

${ }^{27}$ Mira. (2018). Interviews related to the Optimization of the Application of Legal Aid for the Poor in the Sukabumi City Region. Sukabumi City.

${ }^{28}$ Febrian. (2018). Interviews related to the Optimization of the Application of Legal Aid for the Poor in the Sukabumi City Region. Sukabumi City.

${ }^{29}$ Faizal, I. (2018). Interviews related to the Optimization of the Application of Legal Aid for the Poor in the Sukabumi City Region. Sukabumi City.

${ }^{30}$ Yosep. (2018). Interviews related to the Optimization of the Application of Legal Aid for the Poor in the Sukabumi City Region. Sukabumi City.
} 
quite large for the amount of his case every one month rolling in the court cases it can be up to approximately 10-20 cases. Especially for poor people, but most often the case that many, i.e. criminal case compared with a civil case that is not too much. It is because the Legal Adviser did not accompany most cases that cannot afford it. Then based on the literature study, the result for the spread of information about the state legal aid as follows:

$\begin{array}{ll}\text { OBH ratio } & : \text { The number of poor people: } \\ 405 \mathrm{OBH} & : 26.58299 \text { million poor people } \\ 1 \mathrm{OBH} & : 65637 \text { people } \\ \text { The smallest ratio } 1 \mathrm{OBH} & : 9139 \text { poor (Jakarta) }\end{array}$

Based on previous data, it is known that the ratio of OBH by the number of poor people according to researchers OBH comparison between the number ratio with the number of poor people when seen from all parts of Indonesia 1 OBH should help the poor society with the number 9139 was a very heavy burden. Therefore, the need for the addition of $\mathrm{OBH}$ so much better in helping the poor. As for the distribution of $\mathrm{OBH}$ in districts/ municipalities when seen by the number of districts/cities with OBH: 127 (only 25\%) Number of urban districts without $\mathrm{OBH}$ : 389 , then obtained a description that the distribution of OBH in districts/cities still not up to its spread to areas of the city/county, only about $25 \%$ with the number of $\mathrm{OBH}$ cities/districts.

If withdrawn completely red, the conditions of the deployment of only $25 \%$ of legal aid for every area of the city/county, and as much as $75 \%$ city/country that is not his OBH. These conditions constrain the spread of legal aid in Indonesia, so in practice ineffective by the people who need legal help. Especially the city of Sukabumi classified has approximately 400 cases every year, even every month can reach 10 to 20 cases. However, not all cases go to the prosecutor and the court, because the evidence is still incomplete and the investigation process as well as the dismissal of the case or SP3 because of insufficient evidence. Conditions indicate that $\mathrm{LBH} / \mathrm{OBH}$ should be more intensive guidance to avoid technical obstacles.

\section{Recommendations to the Government in the administration of legal aid}

Legal Aid Act is a means state in its function as a state of law, where the state has the authority to determine the means of the important aspects of legal aid for the poor or a certain group of people. These aspects are aspects of the formulation of the rule of law, oversight aspects of the legal aid delivery mechanisms, and aspects of public education for the rule of law that has been created can be internalized ${ }^{31}$, Of the role and function of government/state in the administration of legal aid efforts have not been effective and necessary to

\footnotetext{
${ }^{31}$ Suyogi Imam Fauzi, Inge Puspita Ningtyas, Op.Cit., pp.50-72.
} 
evaluate why implementation is uneven legal assistance to the affected areas, especially in the area of the town of Sukabumi. According to the view Ms Mira $^{32}$ who said that needs to be disseminated to the good public routine that counselling, seminars and more to provide an understanding of the legal aid budget problems for legal aid for the poor is necessary to study what is the problem, and other problems ".

$\mathrm{Mr}$ Febrian ${ }^{33}$ said that the need to socialize the routine of government and law enforcement agencies about the importance of legal aid, the budget for legal aid need to be improved, the need for additional quantity of advocates in the area to help the handling of legal aid for the poor people, if necessary, every problem case criminal law should use legal counsel if necessary so that the public sense of justice.

Mr Faizal ${ }^{34}$ said that the problem is mainly the issue of legal aid is not separated with a budget of legal aid provided by the Government either through state and local budgets. The APBD in Sukabumi is no regulation rules governing the legal aid budget.

Mr. Yosep ${ }^{35}$ said that LBH especially in the city of Sukabumi big my expectations for the government to be given access to legal aid for the regions, especially in the city of Sukabumi in order to be considered, because the distribution of rights to legal aid application has not been evenly distributed, especially in areas which are lacking or have not channelled in fulfilment of the rights of legal aid for the poor in the area. Based on the overall exposure of the informant obtained several recommendation for the provision of legal aid in the future are:

a. Organised socialisation legal aid for poor people through seminars and counselling to understand the role and function of $\mathrm{LBH} / \mathrm{OBH}$ in Sukabumi.

b. Doing pick the ball into the community to find the aspirations, concerns, and problems related to legal issues.

c. You are optimizing the legal aid budget from the state budget and local government to set in Local Rule (Perda).

\section{Conclusion}

\footnotetext{
${ }^{32}$ Mira. (2018). Interviews related to the Optimization of the Application of Legal Aid for the Poor in the Sukabumi City Region. Sukabumi City.

${ }^{33}$ Febrian. (2018). Interviews related to the Optimization of the Application of Legal Aid for the Poor in the Sukabumi City Region. Sukabumi City.

${ }^{34}$ Faizal, I. (2018). Interviews related to the Optimization of the Application of Legal Aid for the Poor in the Sukabumi City Region. Sukabumi City.

${ }^{35}$ Yosep. (2018). Interviews related to the Optimization of the Application of Legal Aid for the Poor in the Sukabumi City Region. Sukabumi City.
} 
Based on the foregoing discussion it can be concluded that the optimization of the application of legal aid for the poor in the city of Sukabumi include: (1) the duties and functions of the Law Enforcement Regarding Legal Aid is to implement the mandate of Law Advocates No. 18 of 2003 in accordance with Article 14 to Article 20 and Article 22 that every advocate shall help poor people who need help; (2) the effectiveness of judicial assistance is considered good enough, because the assistance program is kept up done and still need some improvement in the implementation process; (3) approximately $20 \%$ of people with lawsuit over a five-year sentence received assistance legal assistance, and the quantity of the absence of correspondence between the number of poor people who need help with the total number of $\mathrm{OBH}$; Based on each of the previous conclusion, then there is a number of recommendations in order to optimize the application of legal aid for the poor in the city of Sukabumi namely:

1. Policymakers and interest should review, understand, and improve the actualisation of legislation governing the provision of legal aid to the poor.

2. Law enforcement agencies should draw up a new strategy more innovative in providing legal assistance to the community such as using the concept of "proactive" to the people directly.

3. Policymakers and interest should be mapped at the same time increasing the number of $\mathrm{OBH}$ in accordance the quantity of poor people in the region.

4. Law enforcement agencies should disseminate massively to the public through scientific meetings, studies, dissemination of information through social media, or using information in graphics entitled "Legal Aid to the Poor" which is packed with interesting.

\section{Acknowledgements}

We thank everyone who has helped and supported in this study include:

1. LPPM Universitas Muhammadiyah Sukabumi which has provided advice and support in this study

2. DRPM Kemenristekdikti who have financed so that the process and the completion of this study can proceed smoothly

3. Police Resort Kota Sukabumi as a resource so that the study can proceed smoothly

4. State Attorney Kota Sukabumi as a resource so that the study can proceed smoothly

5. Posbakum DPC District Court of the city of Sukabumi as a resource so that the study can proceed smoothly,

6. LBH DPC Congress of Indonesian Advocates (KAI) Sukabumi as a resource so that the study can proceed smoothly. 
7. And to Iyus Maryani, SH, Eriska Ginalita Dwi Putri, SHMH, and Arif Widianto, MP have helped in this research so that it can be resolved properly.

\section{A. Book}

\section{Bibliography}

Hanitijo, R. (1983). Metode Penelitian Hukum dan Jurimetri. Bogor: Ghalia Indonesia.

Ibrahim, J. (2008). Teori dan Metodologi Penelitian Hukum Normatif. Malang: Bayumedia Publishing.

Marzuki, P. M. (2005). Penelitian Hukum. Surabaya: Kencana.

\section{B. Journal and Article}

Suyogi Imam Fauzi, Inge Puspita Ningtyas, "Optimalisasi Pemberian bantuan hukum demi terwujudnya Access to Law and Justice bagi Rakyat Miskin= Optimization of Legal Assistance to The Fullest Access to Law and Justice for Poor People". Jurnal Konstitusi, Vol.15 No.1, (2018), https://doi.org/10.31078/jk1513 .

Tri Astuti Handayani, "Bantuan Hukum bagi Masyarakat Tidak Mampu dalam Perspektif Teori Keadilan Bermartabat", Jurnal Refleksi Hukum, Vol. 9 No.1, (2015), https://doi.org/10.24246/jrh.2015.v9.i1.p15-24

Himawan Setianto, "Bantuan Hukum bagi Terdakwa Tindak Pidana di Bidang Pertambangan pada Tahap Penuntutan". Jurnal Arena Hukum, Vol.6 No.3, (2013), https://doi.org/10.21776/ub.arenahukum.2013.00601.5 .

Krustiyati, A, "Optimalisasi Perlindungan dan Bantuan Hukum Pekerja Migran melalui Promosi Konvensi Pekerja Migran tahun 2000", Dinamika Hukum, Vol. 13 No.1, (2012).

Mustika Kusumawati, "Peranan dan Kedudukan Lembaga Bantuan Hukum sebagai Access to Justice bagi Orang Miskin", Jurnal Arena Hukum, Vol. 9 No.2, (2016), https://doi.org/10.21776/ub.arenahukum.2016.00902.3 .

Musjtari, D. N. "Pembangunan Kesadaran Hukum Masyarakat Dusun Jetis, Desa Jetis, Kecamatan Saptosari, Kecamatan Gunung Kidul", Jurnal Abdimas, Vol. 22 No.22, (2015).

Authors: Iwan Pujiarto, Syafruddin Kalo, Edy Ikhsan, "Pelaksanaan Pemberi Bantuan Hukum Dikaitkan dengan Bantuan Hukum Dikaitkan dengan Undang-undang No. 16 tahun 2011 tentang Bantuan Hukum", Jurnal Arena Hukum, Vol. 8 No.16, (2011), https://doi.org/10.21776/ub.arenahukum.2015.00803.2.

\section{Legislations}


Law Number 48 on 2009 of Judicial Power.

Law Number 16 on 2011 of Legal Aid.

D. World Wide Web and Interview

Faizal, I. (2018). Interviews related to the Optimization of the Application of Legal Aid for the Poor in the Sukabumi City Region. Sukabumi City.

Febrian. (2018). Interviews related to the Optimization of the Application of Legal Aid for the Poor in the Sukabumi City Region. Sukabumi City.

Mira. (2018). Interviews related to the Optimization of the Application of Legal Aid for the Poor in the Sukabumi City Region. Sukabumi City.

Yosep. (2018). Interviews related to the Optimization of the Application of Legal Aid for the Poor in the Sukabumi City Region. Sukabumi City. Pujiono. (2010). Bantuan Hukum dalam Perspektif Tanggungjawab Negara. Retrieved September 15, 2018, from http://www.mitrahukum.org/publikasi/opini/bantuan-hukum-dalamperspektif tanggungjawab-negara. 